\title{
PENGARUH DIET KETOGENIK TERHADAP PROLIFERASI DAN KETAHANAN SEL PADA JARINGAN PANKREAS
}

\author{
Esa Indah Ayudia Tan ${ }^{1}$, Irfannuddin Irfannuddin², Krisna Murti ${ }^{3}$ \\ ${ }^{1}$ Fakultas Kedokteran dan IImu Kesehatan Universitas Jambi \\ ${ }^{2}$ Bagian Fisiologi dan Fisika Medik Fakultas Kedokteran Universitas Sriwijaya \\ ${ }^{3}$ Bagian Patologi Anatomi Fakultas Kedokteran Universitas Sriwijaya \\ Korespondensi : Irfan.md@unsri.ac.id
}

\begin{abstract}
The ketogenic diet is a diet that uses a lot of fat as an energy source and reduces carbohydrate and protein consumption when the body does not get enough glucose from carbohydrates, the body usually uses alternative energy sourced from the ketone body, namely acetoacetate and b-hydroxybutyrate. The ketone body comes from the breakdown of fatty acid metabolism in the liver where at the moment the concentration is low in the blood. Ketogenic diet is a diet that uses a lot of fat as an energy source and reduces carbohydrate consumption. The ketogenic diet makes the body burn fat instead of carbohydrates.

The pancreas is the center of control of energy metabolism. The role of metabolism affected by endocrine function of the pancreas is located on the islands of langerhans, in the form of epithelial cells spread throughout the organs. Changes in diet patterns will certainly have an impact on proliferation and apoptosis cell in pancreas.
\end{abstract}

Keywords: ketogenic diet, pancreas, proliferation, cell resistance

\section{ABSTRAK}

Diet ketogenik adalah diet yang menggunakan banyak lemak sebagai sumber energi dan mengurangi konsumsi karbohidrat dan protein ketika tubuh tidak mendapatkan cukup glukosa dari karbohidrat, tubuh biasanya menggunakan energi alternatif yang bersumber dari tubuh keton, yaitu asetoasetat dan bhidroksibutirat. Tubuh keton berasal dari pemecahan metabolisme asam lemak di hati di mana saat ini konsentrasi rendah dalam darah. Diet ketogenik adalah diet yang menggunakan banyak lemak sebagai sumber energi dan mengurangi konsumsi karbohidrat. Diet ketogenik membuat tubuh membakar lemak, bukan karbohidrat.

Pankreas adalah pusat kendali metabolisme energi. Peran metabolisme yang dipengaruhi oleh fungsi endokrin pankreas terletak di pulau-pulau langerhans, dalam bentuk sel-sel epitel yang menyebar ke seluruh organ. Perubahan pola diet tentu akan berdampak pada proliferasi dan sel apoptosis pada pankreas.

Kata Kunci: diet ketogenik, pankreas, proliferasi, resistensi sel

\section{PENDAHULUAN}

Sebelum abad ke-20, obesitas jarang ditemui, tetapi pada 1997 WHO secara resmi menyatakan obesitas sebagai epidemi global. ${ }^{1}$ Pada 2016, angka kejadian obesitas pada orang dewasa dengan usia 18 tahun ke atas mencapai lebih dari 1,9 miliar (39\%). Dari jumlah tersebut, lebih dari 650 juta orang mengalami obesitas. ${ }^{2}$
Obesitas merupakan suatu keadaan dengan adanya akumulasi lemak abnormal atau berlebihan yang dikhawatirkan dapat menimbulkan risiko terhadap kesehatan. Secara ilmiah, penyebab mendasar timbulnya obesitas adalah ketidakseimbangan energi antara kalori yang dikonsumsi dan kalori yang dikeluarkan oleh tubuh. ${ }^{3}$ Pada individu per individu, kombinasi antara kelebihan asupan energi makanan dan kurangnya 
aktifitas fisik dapat menjelaskan sebagian besar kasus obesitas. ${ }^{4}$ Sebagian besar kelebihan energi makanan ini berasal dari meningkatnya konsumsi karbohidrat dan bukan dari konsumsi lemak. ${ }^{5}$

Komplikasi obesitas dapat secara langsung atau secara tidak langsung berhubungan dengan mekanisme yang juga menyebabkan obesitas, seperti asupan diet yang tidak sehat atau akibat gaya hidup kurang bergerak. Kelebihan lemak tubuh merupakan penyebab 64\% kasus diabetes pada pria dan $77 \%$ pada wanita.

Salah satu bentuk upaya untuk memperbaiki status kesehatan agar terhindar dari obesitas adalah dengan melakukan beragam intervensi, salah satunya melalui pola diet (). Diet dapat menghasilkan penurunan berat badan dalam jangka pendek. ${ }^{6}$ Salah satu pola diet yang banyak digunakan saat ini adalah diet ketogenik. Diet ketogenik adalah suatu pola makan yang banyak menggunakan sumber lemak sebagai sumber energi dan mengurangi konsumsi karbohidrat. Diet ketogenik membuat tubuh membakar lemak daripada karbohidrat. Jumlah karbohidrat yang sedikit dalam makanan membuat hepar mengubah lemak menjadi asam lemak dan benda keton. Benda keton inilah yang akan masuk ke otak dan menggantikan glukosa sebagai sumber energi. ${ }^{7}$ Diet ketogenik mempertahankan tubuh dalam keadaan ketosis, yang ditandai dengan peningkatan D-b-hydroxybutyrate dan acetoacetate. Badan keton ini menggantikan kedudukan glukosa yang sebelumnya dihasilkan dari karbohidrat. Diet ketogenik selain digunakan untuk menurunkan berat badan juga digunakan pada pasien diabetes mellitus, dimana diet ketogenik dapat membantu mengurangi kadar gula darah. Dengan demikian, diet ketogenik ini mungkin dapat mengurangi kebutuhan pasien diabetes akan pengobatan. ${ }^{8}$

Pankreas merupakan pusat kontrol metabolisme energi. Peran metabolisme dipengaruhi oleh fungsi endokrin pankreas terletak pada pulau-pulau langerhans, berupa sel-sel epitel yang tersebar diseluruh organ. Dua hormon yang mempengaruhi metabolisme karbohidrat dihasilkan oleh jaringan pulau-pulau langerhans yaitu insulin oleh sel Beta dan glukagon oleh sel alfa. ${ }^{9}$ Perubahan pola diet tentu akan berdampak pada insulin dan glukagon.

Protein Ki-67 adalah penanda seluler untuk proliferasi. ${ }^{10}$ Ki-67 dapat ditemukan pada semua sel yang berproliferasi, baik sel normal maupun sel tumor sehingga dapat digunakan sebagai penanda dari kecepatan proliferasi sel. ${ }^{11}$

TUNEL adalah metode untuk mendeteksi fragmentasi DNA apoptosis, yang banyak digunakan untuk mengidentifikasi dan mengukur sel-sel apoptosis, atau untuk mendeteksi kerusakan DNA berlebihan pada sel-sel individual. Pengujian ini bergantung pada penggunaan terminal deoxynucleotidyl transferase (TdT), sebuah enzim yang mengkatalisis perlekatan deoxynucleotide. Pemeriksaan apoptosis dengan metode TUNEL dapat memberikan gambaranproses apoptosis pada tingkat sel 
tunggal sehingga lebih spesifik dan memiliki akurasi tinggi.

Berdasarkan uraian sebelumnya, terdapat adanya pengaruh penerapan pola diet dengan proliferasi dan apoptosis pada jaringan pancreas. Untuk mengetahui pengaruh mokekuler tingkat sel terhadap proliferasi dan apoptosis sel pankreas tikus yang diberi perlakuan diet ketogenik tersebut maka dalam tulisan ini akan diuraikan bagaimana pengaruh diet ketogenik terhadap sintesis dan stres sel jaringan pankreas tikus.

\section{Pankreas}

\section{Anatomi Pankreas}

$$
\text { Pankreas merupakan }
$$

suatu organ retroperitoneal berupa kelenjar dengan panjang sekitar $15-20 \mathrm{~cm}$ pada manusia. Berat pankreas sekitar 75100 g pada dewasa, dan $80-90 \%$ terdiri dari jaringan asinar eksokrin. Pankreas terbentang dari atas sampai ke lengkungan besar dari perut dan biasanya dihubungkan oleh dua saluran ke duodenum terletak pada dinding posterior abdomen di belakang peritoneum sehingga termasuk organ retroperitonial kecuali bagian kecil kaudanya yang terletak dalam ligamentum lienorenalis. Strukturnya lunak dan berlobulus. ${ }^{12}$
Pankreas dapat dibagi ke dalam empat bagian :

a. Caput Pancreatis, berbentuk seperti cakram dan terletak di dalam bagian cekung duodenum. Sebagian caput meluas di kiri di belakang arteri dan vena mesenterica superior serta dinamakan Processus Uncinatus.

b. Collum Pancreatis, merupakan bagian pankreas yang mengecil dan menghubungkan caput dan corpus pancreatis. Collum pancreatic terletak di depan pangkal vena portae hepatis dan tempat di percabangkannya arteria mesenterica superior dari aorta.

c. Corpus Pancreatis, berjalan ke atas dan kiri, menyilang garis tengah. Pada potongan melintang sedikit berbentuk segitiga

d. Cauda Pancreatis, berjalan ke depan menuju ligamentum lienorenalis dan mengadakan hubungan dengan hilum lienale. 


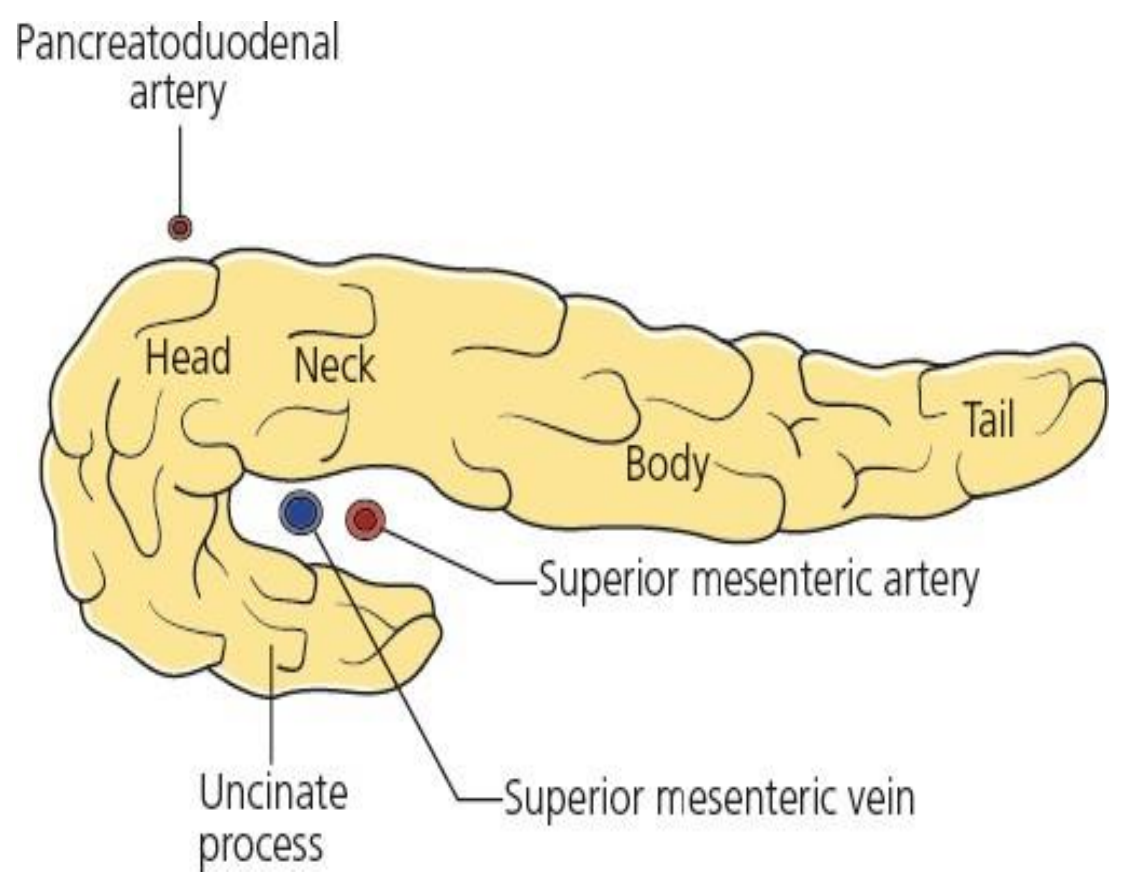

Gambar 1. Pankreas pada potongan transversal terdiri dari head, neck, body, dan tail. Tampampak arteri mesentrika superior dan vena mesentrika superior ${ }^{13}$

\section{Histologi Pankreas}

\section{a. Bagian Eksokrin}

Komponen eksokrin

membentuk sebagian besar pankreas dan terdiri dari asini serosa dan sel zimogenik yang tersusun rapat dan membentuk banyak lobulus kecil. Asinus berbentuk tubular, dikelilingi lamina basal dan terdiri atas 5- 8 sel berbentuk piramid yang tersusun mengelilingi lumen sempit. Tidak terdapat sel mioepitel . Diantara asini, terdapat jaringan ikat halus mengandung pembuluh darah, pembuluh limfe, saraf dan saluran keluar. ${ }^{14}$

b. Bagian Endokrin Komponen endokrin pankreas tersebar di seluruh organ berupa pulau sel endokrin yang disebut insula pancreatica (pulau Langerhans). Pulau Langerhans, tersebar di seluruh pankreas dan tampak sebagai massa bundar, tidak teratur, terdiri atas sel pucat dengan banyak pembuluh darah yang berukuran $76 \times 175 \mathrm{~mm}$ dan berdiameter 20-300 mikron tersebar di seluruh pankreas, walaupun lebih banyak ditemukan di kauda daripada kaput dan korpus pancreas. Dengan pewarnaan khusus, sel-sel pulau Langerhans terdiri dari empat macam:

1. Sel Alfa, sebagai penghasil hormon glukagon. Glukagon meningkatkan kadar glukosa darah 


$\begin{array}{ll}\text { dengan mempercepat } & \text { hormon somatostatin. } \\ \text { perubahan glikogen, asam } & \text { Hormon ini menurunkan } \\ \text { amino, dan asam lemak di } & \text { dan menghambat aktivitas } \\ \text { hepatosit menjadi glukosa. } & \text { sekretorik sel alfa dan sel } \\ 2 \text { Sel Beta, sebagai } & \text { beta melalui pengaruh } \\ \text { penghasil hormon insulin. } & \text { lokal di dalam insula } \\ \text { Insulin menurunkan kadar } & \text { pancreatica. } \\ \text { glukosa darah dengan } & \text { Sel } \mathrm{F}, \text { mensekresi } \\ \text { meningkatkan transpor } & \text { polipeptida pankreas yang } \\ \text { membran glukosa ke } & \text { menghambat } \\ \text { dalam hepatosit, otot, dan } & \text { pembentukan } \\ \text { sel adiposa. } & \text { pankreas dan sekresi } \\ \text { 3. Sel Delta, mensekresikan } & \text { alkali. }\end{array}$

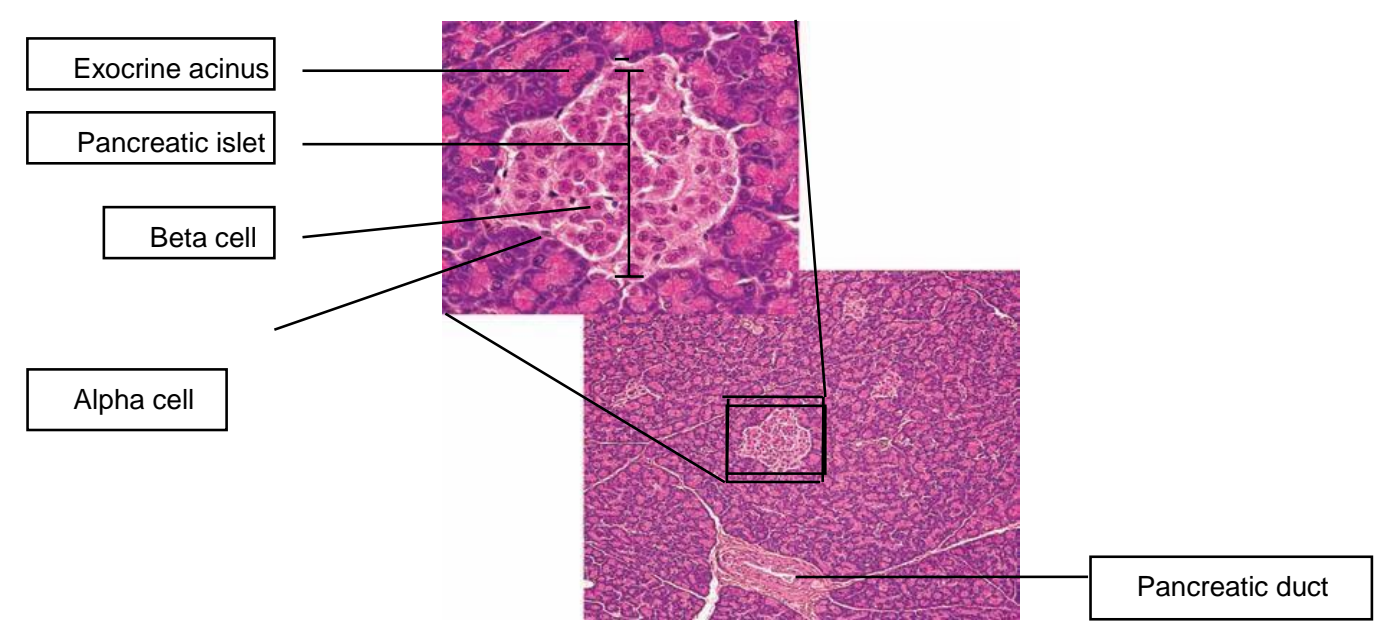

Gambar 2. Histologi Pankreas, tampak Pulau Langerhans, sel beta, dan sel alfa di antara sel asini $^{14}$

\section{Fisiologi Pankreas}

Pankreas merupakan organ pencernaan yang memiliki fungsi, yaitu:

1. Sebagai eksokrin, menghasilkan getah pankreas yang mengandung bikarbonat dan 20 enzim digestif yang berbeda. Enzim ini termasuk (1) amilase, yang membantu mencerna starch; (2) tripsin, yang membantu mencerna protein; dan (3) lipase, yang membantu mencerna trigliserida.

2. Sebagai endokrin, menghasilkan hormon insulin, glukagon, somatostatin dan polipeptida pankreas. 


\section{Obesitas}

Definisi

Menurut NCBI, obesitas merupakan suatu keadaan dengan adanya akumulasi lemak abnormal atau berlebihan yang dikhawatirkan dapat menimbulkan risiko terhadap kesehatan. .

Klasifikasi

Indeks massa tubuh atau BMI adalah metode yang sederhana dan banyak digunakan untuk memperkirakan massa lemak tubuh.15 IMT sangat erat hubungannya dengan persentase lemak tubuh dan total lemak tubuh.18 Persentase lemak tubuh adalah total lemak tubuh yang dinyatakan sebagai persentase dari total berat badan. Tidak ada definisi obesitas yang diterima secara umum berdasarkan total lemak tubuh. Sebagian besar peneliti telah menggunakan $>25 \%$ pada pria, dan> $30 \%$ pada wanita, sebagai titik potong untuk menentukan obesitas. 19

\section{Epidemiologi}

Sebelum abad ke-20, obesitas jarang ditemui.16 , tetapi pada 1997 WHO secara resmi menyatakan obesitas sebagai epidemik global.1 Pada 2016, angka kejadian obesitas pada orang dewasa dengan usia 18 tahun ke atas mencapai lebih dari 1,9 miliar (39\%). Dari jumlah tersebut, lebih dari 650 juta orang mengalami obesitas (13\%).2 Dahulu, obesitas dianggap sebagai masalah negara-negara berpenghasilan tinggi, namun saat ini angka obesitas meningkat di

6. Meningkatnya etnik dan kelompok umur yang secara proporsional cenderung lebih berat seluruh dunia dan mempengaruhi baik dunia maju maupun dunia berkembang.17

\section{Etiologi}

Secara ilmiah, penyebab mendasar timbulnya obesitas adalah ketidakseimbangan energi antara kalori yang dikonsumsi dan kalori yang dikeluarkan oleh tubuh.3 Pada individu per individu, kombinasi antara kelebihan asupan energi makanan dan kurangnya aktivitas fisik dapat menjelaskan sebagian besar kasus obesitas Sebaliknya pada masyarakat, obesitas yang meningkat mungkin disebabkan karena mudahnya mendapatkan makanan dan banyaknya makanan yang enak.20 Sebagian besar kelebihan energi makanan ini berasal dari meningkatnya konsumsi karbohidrat dan bukan dari konsumsi lemak. 5

Penyebab meningkatnya obesitas antara lain : 21

1. Kurang tidur

2. Berbagai pengganggu endokrin (polutan lingkungan yang memengaruhi metabolisme lipid

3. Menurunnya variabilitas suhu lingkungan

4. Menurunnya jumlah perokok, karena merokok menekan nafsu makan

5. Meningkatnya penggunaan obatobatan yang menyebabkan kenaikan berat badan (misalnya, antipsikotik atipikal),

7. Kehamilan pada usia lebih tua (yang dapat menyebabkan 
kerentanan anak mengalami obesitas)

8. Epigenetik faktor risiko yang diturunkan antar generasi,

9. Seleksi alam untuk BMI yang lebih tinggi

10. Pasangan asortatif yang menyebabkan meningkatnya konsentrasi faktor risiko obesitas

\section{Energy Expenditure}

Pada saat tubuh mendapatkan asupan makanan (karbohidrat, protein, lemak), sebagian besar karbohidrat yang diserap oleh tubuh, dalam bentuk glukosa, akan mengalami katabolisme untuk menghasilkan energi. Sebagian sisa glukosa tersebut akan diubah menjadi glikogen oleh sel-sel otot, serta diubah menjadi lemak (triasilgliserol) oleh sel-sel adiposa. Lemak juga mengalami katabolisme oleh sel-sel tubuh untuk menghasilkan energi. Hanya sedikit ingested fat yang disimpan dalam tubuh sebagai cadangan. Protein diserap dalam bentuk asam amino dan digunakan oleh sel-sel tubuh untuk membentuk protein, hormon dan enzim.

Pada keadaan tubuh tidak mendapatkan asupan makanan, atau saat kebutuhan energi meningkat drastis, kadar glukosa tubuh tidak dapat mencukupi kebutuhan energi tersebut dan kadarnya akan terus menurun, dengan terjadinya katabolisme glukosa menjadi energi. Sedangkan tubuh harus mempertahankan kadar glukosa darah karena otak secara normal hanya menggunakan glukosa sebagai sumber energinya. Maka dari itu, tubuh mengupayakan pembentukan glukosa dengan mengaktifkan proses glukoneogenesis.

Selama 24 jam puasa, proses glukoneogenesis menghasilkan sekitar 180 gram glukosa dan men-supply 712 kcal bagi tubuh. Namun, pada keadaan normal energy expenditure orang dewasa sekitar 1500-3000 kcal per hari, sehingga glukoneogenesis saja tidak dapat mengcover seluruh kebutuhan energi tubuh. Dengan demikian, tubuh melakukan suatu penyesuaian agar energy expenditure dapat tercukupi dalam melaksanakan aktivitas sehari-hari dan otak tetap mendapatkan sumber energinya.

Kebanyakan organ dan jaringan tubuh akan mengurangi katabolisme glukosanya dan meningkatkan penggunaan cadangan lemaknya untuk kemudian diubah menjadi sumber energi utama. Penyesuaian metabolisme ini, disebut glucose sparing, bertujuan untuk menghemat glukosa yang diproduksi oleh hati agar dapat digunakan secara maksimal oleh sistem saraf.

Proses glucose sparing diawali dengan lipolisis, dimana triasilgliserol diubah menjadi gliserol dan asam lemak. Gliserol akan masuk ke jalur glukoneogenesis sedangkan asam lemak dapat diubah menjadi energi melalui dua jalur, sebagian masuk jalur oksidasi- $\beta$ menjadi asetil Ko-A, serta sebagian menjadi badan keton melalui jalur ketogenesis. Badan-badan keton ini merupakan penyedia energi utama bagi sebagian besar jaringan-jaringan tubuh pada keadaan puasa lama, termasuk otak. 


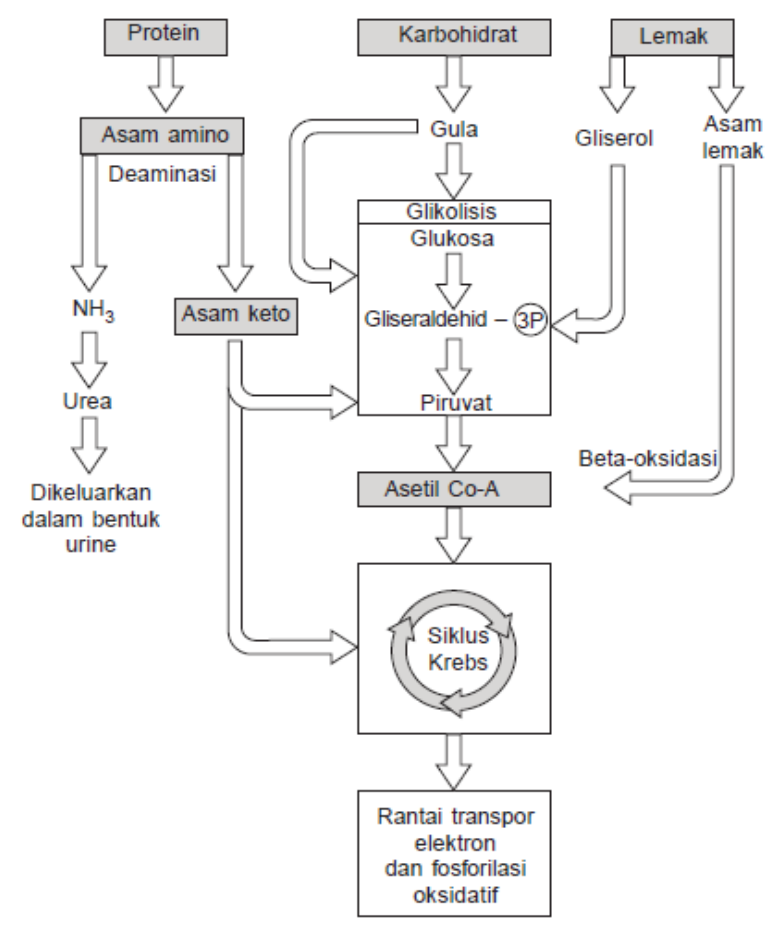

Gambar 3. Ketiga tahap katabolisme dari karbohidrat, lemak, dan protein yang diubah menjadi Acetyl CoA dan masuk ke dalam Siklus Kreb's ${ }^{28}$

\section{Glukoneogenesis}

Glukoneogenesis merupakan suatu proses yang terjadi di hati dan ginjal untuk membentuk glukosa atau glikogen dari prekursor nonkarbohidrat, seperti asamasam amino glukogenik, laktat, gliserol, dan propionat. Glukoneogenesis memiliki peranan penting dalam mempertahankan kadar glukosa darah setelah puasa semalaman. Selain itu, glukoneogenesis juga membersihkan laktat yang dihasilkan oleh jaringan otot, serta gliserol yang dihasilkan oleh jaringan adiposa. ${ }^{28}$

Pada proses glukoneogenesis, prekursor-prekursor nonkarbohidrat akan diubah terlebih dahulu menjadi zat-zat antara. Laktat dapat diubah menjadi piruvat oleh enzim laktat dehidrogenase, asam amino dapat diubah menjadi oksaloasetat, dan gliserol dapat diubah menjadi dihidroksiaseton fosfat. 


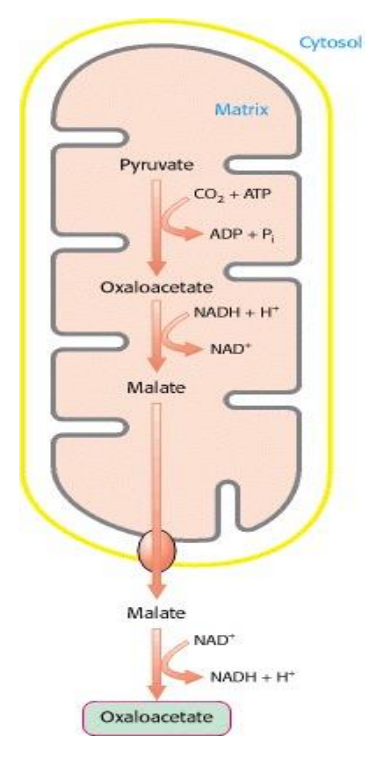

Gambar 4. Compartmental cooperation pada gluconeogenesis. Di dalam mitokondria, piruvat diubah menjadi oksaloasetat dan kemudian menjadi malate. Malate keluar dari mitokondria dan diubah menjadi oksaloasetat di sitosol ${ }^{9}$

Jalur glukoneogenesis bukan sepenuhnya kebalikan dari jalur glikolisis. Pada glukoneogenesis, piruvat tidak bisa langsung diubah menjadi fosfoenolpiruvat, melainkan harus melalui jalur "memutar", yaitu diubah menjadi oksaloasetat di dalam mitokondria, lalu menjadi malat, dan dikeluarkan dari mitokondria ke sitosol untuk kemudian diubah lagi menjadi oksaloasetat. Oksaloasetat kemudian akan diubah menjadi fosfoenolpiruvat oleh enzim fosfoenolpiruvat karboksikinase. Fosfoenolpiruvat akan mengikuti jalur reversibel glikolisis sampai menjadi fruktosa-1,6-bifosfat, lalu dengan bantuan fruktosa-1,6-bifosfatase akan diubah menjadi fruktosa-6-fosfat, lalu manjadi glukosa-6-fosfat. Namun, glukosa-6-fosfat tidak bisa langsung diubah menjadi glukosa, sehingga glukosa-6-fosfat terlebih dahulu masuk ke retikulum endoplasma halus untuk diubah menjadi glukosa oleh glukosa-6-fosfatase. Glukosa kemudian akan dikeluarkan oleh sel-sel hati ke peredarah darah. ${ }^{27}$ 


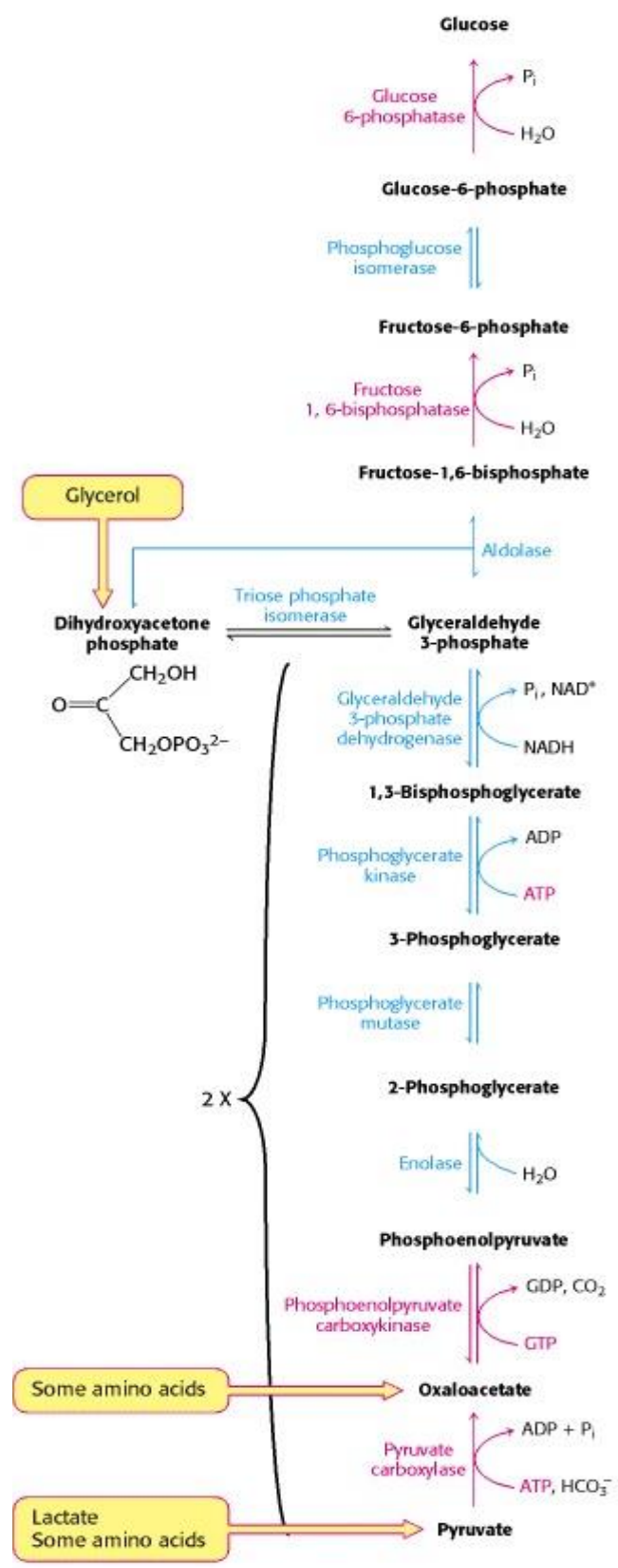

Gambar 5. Jalur gluconeogenesis. Glukosa diubah menjadi glukosa 6 phosphat dan diubah menjadi fruktosa 6 phosphat kemudian diubah lagi menjadi fruktosa 1,6 biphosphat dan natinya akan menjadi piruvat dengan bantuan enzim ${ }^{9}$

Selain laktat, gliserol juga merupakan prekursor nonkarbohidrat yang dapat masuk ke jalur glukoneogenesis. Gliserol terlebih dahulu diubah menjadi gliserol-3-fosfat kemudian menjadi dihidroksiaseton fosfat, lalu menjadi fruktosa-1,6-bifosfat. Fruktosa-1,6-bifosfat akan diubah menjadi glukosa melalui jalur yang sudah dijelaskan sebelumnya. Dengan begitu, glukosa darah dapat dipertahankan kadarnya. 


\section{Diet Ketogenik}

Diet ketogenik (DK) merupakan diet tinggi lemak dan rendah karbohidrat yang akan menciptakan keadaan ketosis bagi tubuh (Wisnu dkk, 2017). Rendahnya karbohidrat yang dikonsumsi akan menurunkan kadar glukosa dalam darah sehingga tubuh menggunakan bahan lain sebagai sumber energi, salah satunya adalah lemak. Pemecahan asam lemak bebas menghasilkan badan keton, yang kemudian akan digunakan jaringan ekstrahepatik untuk menghasilkan energi. Kadar badan keton yang tinggi didalam darah inilah yang disebut sebagai ketosis.

Diet ketogenik semula dikembangkan pada tahun 1920-an sebagai pengobatan epilepsi yang sulit di kontrol. ${ }^{7}$ Eksistensi diet ketogenik kembali naik pada tahun 1990-an saat American Epilepsy Society mengadakan pertemuan untuk membahas efektifitas diet ketogenik yang mungkin lebih tinggi dibandingkan kebanyakan metode pengobatan epilepsi yang baru. ${ }^{7}$

Diet ketogenik juga dikenal sebagai salah satu metode untuk pengobatan obesitas sejak tahun 1960-an sampai sekarang. Selain itu, diet ketogenik juga terbukti memiliki potensi terapeutik dalam berbagai penyakit atau kondisi patologis tubuh, seperti dislipidemia, diabetes, dan tentunya obesitas serta epilepsi. ${ }^{29}$

\section{Ketogenesis}

Ketogenesis adalah jalur metabolisme yang memproduksi badan keton, sebagai sumber energi alternatif bagi tubuh. Keton diproduksi secara fisiologis oleh tubuh dalam jumlah sedikit sebagai sumber energi. Peningkatan regulasi jalur ketogenesis terjadi pada saat simpanan karbohidrat tubuh menurun drastis atau kadar asam lemak meningkat. Pada keadaan puasa, atau selama tidur malam, jumlah badan keton yang dilepaskan ke sirkulasi meningkat, karena tidak adanya asupan glukosa selama puasa dan tidur malam.

Ketogenesis merupakan proses panjang pemecahan asam lemak, yaitu proses oksidasi asam lemak atau oksidasi$\beta$ (beta). Proses ketogenesis berawal dari konversi asam lemak menjadi suatu zat antara aktif, yaitu asil-KoA, dengan bantuan enzim asil-KoA sintetase (tiokinase) di sitoplasma. Asil-KoA kemudian melewati membran luar mitokondria. Namun, untuk dapat melewati membran dalam, asil-KoA harus terlebih dahulu diubah menjadi asilkarnitin dengan bantuan carnitine palmitoyltransferase-I (CPT-1), yang terdapat di membran luar mitokondria.

Asilkartinin menembus membran dalam dengan bantuan kartinin-asilkartinin translokase sebagai exchange transporter yang terletak di membran dalam mitokondria. Di dalam matriks mitokondria, asilkartinin diubah lagi menjadi asil-KoA dengan bantuan enzim carnitine palmitoyltransferase-II (CPT-2).

Proses selanjutnya adalah serangkaian reaksi pemutusan yang akan mengkonversi asil-KoA menjadi asetil-KoA. Pertama, asil-KoA akan diubah menjadi $\Delta^{2}$ trans-enoil-KoA. Proses ini memerlukan FAD dan dikatalis oleh asil-KoA dehydrogenase. Selanjutnya, $\Delta^{2}$-enoil-KoA 
hydrolase akan mengubah $\Delta^{2}$-trans-enoilKoA menjadi 3-hidroksiasil-KoA, yang kemudian akan diubah menjadi 3-ketoasilKoA oleh L-(+)-3-hydroxyacyl-CoA dehydrogenase dengan koenzim $\mathrm{NAD}^{+}$. 3ketoasil-KoA akan dipecah oleh tiolase menjadi asetil-KoA dan asil-KoA baru. Asetil-KoA kemudian akan masuk ke siklus Krebs, sedangkan asil-KoA baru akan kembali mengalami reaksi oksidatif menjadi asetil-KoA.

Pada keadaan produksi asetil-KoA berlebihan dan siklus Krebs mengalami overload, asetil-KoA digunakan untuk menghasilkan badan keton. Penurunan jumlah oksaloasetat dapat mengganggu kemampuan siklus asam sitrat memetabolisme asetil-KoA dan mengalihkan oksidasi asam lemak menuju ketogenesis. Asetil-KoA akan dikonversi menjadi hydroxymethylglutaryl CoA (HMG-KoA) dengan bantuan HMG-KoA sintase. HMG-KoA akan diubah menjadi asetoasetat, yang dikatalis oleh HMGKoA liase. Dengan bantuan enzim $D(-)$ 3-hydroxybutyrate dehydrogenase, asetoasetat dikonversi menjadi $\mathrm{D}(-)-3-$ hidroksibutrat. Asetoasetat juga dapat mengalami dekarboksilasi spontan menjadi aseton, yang diekskresikan melalui urin ataupun sistem pernapasan. Asetoasetat, $\mathrm{D}(-)$-3-hidroksibutrat, dan aseton merupakan produk dari ketogenesis, yang dikenal sebagai badan-badan keton.

\section{Oksidasi Badan Keton}

Badan-badan keton digunakan jaringan ekstrahepatik sebagai bahan bakar untuk menghasilkan energi. Asetoasetat dan 3-hidroksibutirat di transpor dari hati ke jaringan ekstrahepatik, misalnya otot, melalui sirkulasi darah. Sesampainya di jaringan ekstrahepatik, 3-hidroksibutirat terlebih dahulu dikonversi menjadi asetoasetat, sebelum diaktifkan menjadi asetoasetil-KoA oleh enzim suksinil-KoAasetoasetat KoA transferase. AsetoasetilKoA dikonversi menjadi asetil-KoA oleh enzim tiolase, dan selanjutnya masuk ke siklus asam sitrat untuk manghasilkan energi.

Asam asetoasetat dan 3hidroksibutirat merupakan asam berkekuatan sedang yang akan di-buffer jika terdapat di dalam darah atau jaringan. Namun, bila kedua badan keton tersebut dikeluarkan terus-menerus dalam jumlah besar, jumlah badan keton dalam darah akan yang melebihi kadar normal, yang disebut ketonemia (hiperketonemia), dan disebut ketonuria bila ditemukan di dalam urin. Secara keseluruhan, kedua keadaan tersebut disebut ketosis. Ketosis ringan dapat ditemukan pada keadaan kelaparan, namun pada diabetes melitus, ketosis berat dapat terjadi. Keadaan ketosis bila terus dibiarkan dapat mengganggu keseimbangan asam-basa tubuh, dan akhirnya terjadi ketoasidosis.

\section{Ki-67}

\section{Penanda proliferasi Ki-67}

Ki-67 adalah protein inti yang dapat dijumpai selama fase aktif dari siklus sel (G1, S, G2, dan M). Ki-67 tampak jelas 
pada sel-sel yang berproliferasi dan kurang jelas dalam sel diam. Antibody Ki-67 sering digunakan untuk mendeteksi proliferative sel-sel dalam studi klinis. ${ }^{30}$ Protein Ki-67 khususnya digunakan untuk mitosis perikromosomal. ${ }^{31}$

\section{Struktur dan fungsi protein Ki-67}

Ki-67 memiliki waktu paruh 1 sampai 1,5 jam. Protein ini timbul selama fase aktif pada siklus sel (G1, S, G2, dan M), tetapi hilang pada fase G0. Pada fase selanjutnya setelah mitosis (selama anafase dan telofase), terjadi penurunan drastis level protein Ki-67. Ekspresi protein Ki-67 (pKi67) dihubungkan dengan aktivitas proliferasi sel-sel intrinsik sehingga dapat dipakai sebagai penanda agresivitas tumor. ${ }^{32}$ Protein Ki-67 sebagai penanda yang berhubungan dengan proliferasi, dideteksi pada level yang rendah pada fase G1 dan S dan meningkat pada awal mitosis. Setelah fase mitosis terjadi penurunan drastis level Ki-67. Nilai prognostik Ki-67 telah diteliti dalam sejumlah penelitian sebagai penanda pada kanker payudara, jaringan lunak, paru-paru, prostat, leher Rahim, dan sistem saraf pusat. ${ }^{33}$

\section{TUNEL}

\section{Metode TUNEL}

TUNEL adalah metode untuk mendeteksi fragmentasi DNA apoptosis, yang banyak digunakan untuk mengidentifikasi dan mengukur sel-sel apoptosis, atau untuk mendeteksi kerusakan DNA berlebihan pada sel-sel individual. [Pengujian ini bergantung pada penggunaan terminal deoxynucleotidyl transferase (TdT), sebuah enzim yang mengkatalisis perlekatan deoxynucleotide. Ini juga dapat memberi label sel-sel yang DNAnya rusak dengan cara lain selain saat apoptosis.

\section{Apoptosis}

Apoptosis adalah kematian sel melalui mekanisme genetik dengan kerusakan/fragmentasi kromosom atau DNA. Apoptosis dibedakan menjadi dua kelompok, yaitu apoptosis fisiologis dan apoptosis patologis. Apoptosis fisiologis adalah kematian sel yang diprogram (programmed cell death). Proses kematian sel erat kaitannya dengan enzim telomerase. Pada sel embrional, enzim ini mengalami aktivasi sedangkan pada sel somatik enzim ini tidak mengalami aktivasi, kecuali sel bersangkutan mengalami transformasi menjadi ganas. Telomer yang terletak pada ujung kromosom merupakan faktor yang sangat penting dalam melindungi kromosom. Pada sel normal, telomer akan memendek pada saat pembelahan diri. Apabila ukuran telomer mencapai ukuran tertentu (level kritis) akibat pembelahan berulang, maka sel tersebut tidak dapat melakukan pembelahan diri lagi. Selanjutnya sel akan mengalami apoptosis secara fisiologis.

Sedangkan apoptosis patologis adalah kematian sel karena adanya proses suatu rangsangan. Proses ini dapat melalui beberapa jalur, yaitu aktivitas p53, jalur sitotoksik, disfungsi mitokondria, dan kompleks fas dan ligan. Apoptosis dipicu oleh aktivitas p53 karena sel memiliki gen cacat yang dipicu oleh banyak faktor, 
antara lain bahan kimia, radikal bebas, maupun virus (oncovirus). Gen yang cacat dapat memicu aktivitas beberapa enzim seperti PKC dan CPK-K2 yang dapat memicu aktivitas p53. P53 adalah faktor transkripsi terhadap pembentukan p21. Peningkatan p21 akan menekan semua CDK (Cyclin Dependent Kinase) dengan cyclin, dimana siklus pembelahan sel sangat tergantung pada ikatan kompleks antara CDK dengan cyclin.

Pemilihan metode identifikasi apoptosis tergantung pada beberapa faktor antara lain jenis eksperimen, tipe sel, dan berdasar pengalaman yg telah dilakukan. TUNEL (Terminal deoxyribonucleotidyl transferase dUTP nick end labeling) merupakan salah satu metode deteksi apoptosis dengan memeriksa fragmentasi DNA. Pemeriksaan apoptosis dengan metode TUNEL dapat memberikan gambaran proses apoptosis pada tingkat sel tunggal sehingga lebih spesifik dan memiliki akurasi tinggi.

\section{Mekanisme Apoptosis}

Penelitian menunjukkan bahwa ada dua jalur apoptosis utama: jalur reseptor ekstrinsik atau kematian dan jalur intrinsik atau mitokondria. Namun, sekarang ada bukti bahwa kedua jalur tersebut terhubung dan bahwa molekul dalam satu jalur dapat mempengaruhi yang lain. Terdapat jalur tambahan yang melibatkan sitotoksisitas sel $T$ yang dimediasi dan pembunuhan sel bergantung pada perforin-granzyme. Jalur perforin / granzyme dapat menginduksi apoptosis melalui granzyme $B$ atau granzyme A. Jalur ekstrinsik, intrinsik, dan granzim $B$ bertemu di terminal yang sama, atau jalur eksekusi. Jalur ini diprakarsai oleh pembelahan caspase-3 dan menghasilkan fragmentasi DNA, degradasi protein sitoskeletal dan nuklear, ikatan silang protein, pembentukan badan apoptosis, ekspresi ligan untuk reseptor sel fagositik dan akhirnya diambil oleh sel fagositik. Granzyme A pathway mengaktifkan jalur kematian sel caspaseindependent yang paralel melalui kerusakan DNA beruntai tunggal.

\section{KESIMPULAN}

Pada keadaan tertentu sumber glukosa akan digantikan oleh sumber alternatif seperti lemak dan protein. Pankreas adalah pusat metabolisme. Diet ketogenik merupakan bentuk modifikasi pemanfaatan sumber energi alternatif selain glukosa. Penggunan sumber energi alternatif tersebut tentu akan mepengaruhi kemampuan proliferasi sel pankreas dan ketahanan sel pankreas. Banyak literatur yang telah membuktikan bahwa diet ketogenik dapat memberikan dampak positif terhadap kemampuan proliferasi dan ketahan sel. Akan tetapi beberapa penelitian lainnya menunjukkan bahwa penggunaan diet ketogenik tanpa pengawasan ketat dan dalam jangka waktu lama justru dapat mengakibatkan pengaruh negatif terhadap proliferasi dan ketahanan sel pankreas.

\section{DAFTAR PUSTAKA}


1. Caballero B. 2007. 'The global epidemic of obesity: An overview'. Epidemiol Rev. 29: 1-5.

2. WHO. 2017. https://www.who.int/news-room/fact-sheets/detail/obesity-and-overweight

3. Muralidhar MB, Prasad, Battula K. 2017. Differential Response of Rat Strains to Obesogenic Diets Underlines the Importance of Genetic Makeup of an Individual Towards Obesity. 7(1):9162

4. Lau DC, Douketis JD, Morrison KM, Hramiak IM, Sharma AM, Ur E. 2007. '2006 Canadian clinical practice guidelines on the management and prevention of obesity in adults and children summary'. CMAJ. 176 (8): S1-3.

5. Wright JD, Kennedy-Stephenson J, Wang CY, McDowell MA, Johnson CL. 2004. 'Trends in intake of energy and macronutrients-United States, 1971-2000'.

6. Strychar I. 2006. 'Diet in the management of weight loss'. CMAJ.174 (1): 5663. doi:10.1503/cmaj.045037.

7. Freeman JM, Kossoff EH, Hartman AL. 2007. The Ketogenic Diet: One Decade Later Pediatrics. 119(3): 535-43

8. Wajeed Masood, Kalyan R, Uppaluri. 2015. Ketogenic Diet

9. Harper, V. W Rodwell, P. A Mayes. 1979. Biokimia. Penerbit EGC : Jakarta.

10. Scholzen T, Gerdes J. 2000. 'The Ki-67 protein: from the known and the unknown'. Journal of Cellular Physiology. 182 (3): 311-22

11. Joensuu K, Leidenius M. 2013. ER, PR, HER2, Ki-67 and CK5 in Early and Late Relapsing Breast Cancer Reduced CK5 Expression in Metastases. Libertas Academia. 7: 23-34

12. Ganong, W.F. 2005. Buku Ajar Fisiologi Kedokteran. Edisi ke 22. Penerjemah: Pendit, B.U. judul buku asli: Review of medical Physiology, edisi ke 22. Penerbit Buku Kedokteran EGC. Jakarta.

13. Snell, R. S. 2012. Anatomi Klinis Berdasarkan Sistem. Dialih bahasakan oleh Sugarto L. Jakarta:EGC.

14. Sherwood. 2002. Human Physiology from cell to system, Ebook.

15. Mei Z, Grummer-Strawn LM, Pietrobelli A, Goulding A, Goran MI, Dietz WH. 2002. 'Validity of body mass index compared with other body-composition screening indexes for the assessment of body fatness in children and adolescents'. Am J Clin Nutr. 75 (6): 978-85

16. Haslam D. 2007. 'Obesity: a medical history'. Obes Rev. 8 Suppl 1: 31-6.

17. Tsigosa Constantine; Hainer, Vojtech; Basdevant, Arnaud; Finer, Nick; Fried, Martin; MathusVliegen, Elisabeth; Micic, Dragan; Maislos, Maximo; Roman, Gabriela. 2008. 'Management of Obesity in Adults: European Clinical Practice Guidelines'. The European Journal of Obesity. 1(2): $106-16$

18. Gray DS, Fujioka K. 1991. 'Use of relative weight and Body Mass Index for the determination of adiposity'. J Clin Epidemiol. 44 (6): 545-50.

19. Okorodudu; et al. 2010. 'Diagnostic performance of body mass index to identify obesity as defined by body adiposity: a systematic review and meta-analysis'. International Journal of Obesity. 34: 791-799

20. Drewnowski A, Specter SE. 2004. 'Poverty and obesity: the role of energy density and energy cost'. Am. J. Clin. Nutr. 79 (1): 6-16. PMID 14684391.

21. Keith SW; Redden DT; Katzmarzyk PT; et al. 2006. "Putative contributors to the secular increase in obesity: Exploring the roads less traveled". Int J Obes (Lond). 30 (11): 1585-94.

22. Soetjiningsih, 2004. Buku Ajar: Tumbuh Kembang Remaja dan Permasalahannya. Jakarta : Sagung Seto.

23. Depkes RI. 2003. Manajemen Puskesmas. Jakarta: Depkes RI

24. Almatsier, S. 2003. Prinsip Dasar Ilmu Gizi. PT. Gramedia Pustaka Utama. Jakarta

25. Fatchiyah, E.L., Arumingtyas S., Widyarti, \& Rahayu, S. 2011. Biologi molekuler prinsip dasar analisis. Jakarta: Penerbit Erlangga.

26. Arisman. 2010. Gizi Dalam Daur Kehidupan. Jakarta:Penerbit Buku Kedokteran EGC

27. Kartasapoetra, G., dan H.Marsetyo, 2008. Ilmu Gizi, Korelasi Gizi, Kesehatan dan Produktivitas Kerja. Rineka Cipta, Jakarta.

28. Murray, K. 2006. Illustrated Biochemistry. The Mac Graw Hill Companie; New York. 27ed

29. Paoli. 2014. 'Ketogenic Diet for Obesity: Friend or Foe?'. International Journal Public Health Feb; 11(2) doi: 10.3390/ijerph110202092

30. Dowset M, Nielson TO. 2011. Assesment of Ki67 in Breast Cancer: Recommendations from the International Ki67 Breast Cancer Working Group. J Natl Cancer Inst. 103:1656-1664

31. Van Hooser AA, Yuh P, Herald R. 2005. The Perichromosomal Layer. Chromosoma. 114: 377-388

32. Modlin IM, Moss SF. 2008. Priorities for Improving the Management of Gastroenteropancreatic Neuroendocrine Tumors. J Natl Cancer Inst. 100: 1282-1289

33. Ishihara M, Mukai H. 2013. Retrospective Analysis of Risk Factors for Central Nervous System Metastases in Operable Breast Cancer. Effects of Biologic Subtype and Ki67 Overexpression on Survival. Oncology. 84: 135-14 